\title{
E-LITERACY FOR SKILLS DEVELOPMENT AND EMPLOYEE ENGAGEMENT: THE CASE OF VUT ${ }^{1}$
}

Antoinette Lombard, Director of the e-skills unit at the Vaal University of Technology (VUT), had initiated a skills development and employee engagement project for the Human Resource (HR) Department through offering an e-skills and e-literacy course to the service workers of the University. Service workers included cleaning, gardening, maintenance and electrical workers. After a reasonably successful pilot was completed, she was considering how to move the project forward.

The Vaal University of Technology (VUT) was one of the 26 higher education institutions in South Africa, situated in the southern part of the Gauteng Province. It employed a total of 1241 staff that included academics, non-academics administrators and service workers. VUT consisted of four satellite campuses, with the main campus situated in Vanderbijlpark. The development of service workers or low level employees was normally not the focus of higher education institutions and therefore this category of employees normally lost out on personal development opportunities and were generally disengaged within their institutions. In the case of VUT, management wanted to assist these workers to improve their skills.

Antoinette deemed the e-skills and e-literacy course as the foundation for this development. This course was designed to apply e-skills knowledge to real life challenges for self-development of the staff. The course was introduced to the service workers over a period of 6 months in a facilitated environment. The results showed that most of the participants failed to meet the $60 \%$ pass mark in their initial examination, struggling with the more advanced topics in courses such as mail merge and Excel spreadsheet formulas.

The decision Antoinette faced was how to improve the success rate in the course without compromising its relevance and focus. One option was to change the level of course difficulty by removing the higher level and more difficult topics, without necessarily watering down the ultimate outcomes of the course. Another option was to change the facilitation mode from a totally facilitated environment to a more blended environment. A third option involved additional exercises with more application type questions to instill e-social and e-astuteness principles.

\footnotetext{
${ }^{1}$ Copyright (C 2018, Robert. L. Martin and Antoinette Lombard. This case was prepared for the purpose of class discussion. Names and some information have been disguised. This case is published under a Creative Commons BY-NC license and originally appeared as a chapter in Transforming Society Using ICT: Contemporary Discussion Cases from Africa. Permission is granted to copy and distribute this case for non-commercial purposes, in both printed and electronic formats.
} 


\section{Overview of the Republic of South Africa}

The southernmost tip of Africa was home to a nation on the rise - a place where a warm-spirited and inventive people, great natural wealth and breath-taking landscapes came together to create fresh opportunities and new ways of doing things. This was South Africa of the 21st century: modern, vibrant and productive, rooted in Africa - and in close touch with the world at large. Since the end of apartheid in 1994, a new set of opportunities and challenges to transform society arose and, taking into account the local SA conditions and international best practices, South Africa launched a range of strategic initiatives to accelerate development and growth that would benefit the entire population and defeat poverty and the legacy of under-development. The National Development Plan (NDP) Vision 2030 was the blueprint for development of the country adopted by the national government. The NDP aimed to eliminate poverty and reduce inequality by 2030. According to the NDP, the South African nation could realise these goals by drawing on the energies of its people, growing an inclusive economy, building capabilities, enhancing the capacity of the state, and promoting leadership and partnerships throughout society. The training of South African citizens, in every format available, was going to contribute to the goals of the NDP and it was envisaged that the role of VUT would be to contribute to this training programme.

The Republic of South Africa had a population of about 56 million people, with the Gauteng Province being the most populated of the nine provinces. Gauteng Province had a population of about thirteen million people.

The country had 11 official languages. Although English was widely accepted as the business language in the country, it was only the $4^{\text {th }}$ most spoken language with 4.9 million speakers. According to 2011census data, Zulu was the most widely spoken language in the country with 11.6 million speakers, followed by Xhosa and Afrikaans with 8.15 million and 6.85 million speakers, respectively.

According to the Bill of Rights of South Africa's Constitution, all South Africans had the right to a basic education, including adult basic education and access to further education. The state had an obligation, through reasonable measures, to progressively make education available and accessible. The Skills Development Act governed the roll out of skills development and training in SA. This Act placed the responsibility of developing the skills of employees on employers.

\section{The e-skills project in South Africa}

The e-skills project at the Vaal University of Technology (VUT) started in 2010, after the Deputy Vice Chancellor (DVC) at the time, Prof Alwyn Louw, had attended the first e-skills summit held in Cape Town, South Africa. It was the beginning of an exciting journey with the government focused on eskilling the nation. The e-Skills Institute (eSI), an entity established within the Department of Communication (DOC), was responsible for running the e-skills project. The National e-Skills Plan of Action (NeSPA) resulted from this summit and was reviewed during 2012 and 2013.

To this end, NeSPA 2013 provided the model, identified a planned approach, and called for the emergence of a national entity that would command the support, resources and respect of all government departments, state-owned enterprises as well as the business, education, civil society and organized labour sectors. The approach, which is outlined in the NeSPA 2013 document, has been informed by in-depth investigation of approaches used in Mexico, Cuba, the United States, Kenya, Rwanda, the United Kingdom, Ireland, Australia, New Zealand and Northern and Eastern Europe. NeSPA 2013 served as the framework for the roll out of the e-skills project in South Africa.

Important definitions applicable to the e-skills program in South Arica were the following: 
iNeSI (National e-Skill Institute): “An Institute to be established in terms of the iNeSI Act in line with the Higher Education Act, 1997 (Act No. 101 of 1997 as amended) and National Qualifications Framework Act, 2008 (Act No. 67 of 2008) to address the e-Skills demands and needs in the country and to ensure that education and training respond to the demands and needs of e-Skills in the country.

e-Skills: An e-skill was more than knowing the basics of how to use a computer (computer literacy). While it was essential to be computer literate, the important question was what you could do with your skill. An e-skill meant being able to use technology to actually do something - to actively take part in the world and move ahead.

e-Literacy: The ability of individuals to use digital tools and facilities to perform tasks, solve problems, communicate, manage information, collaborate, create and share content and build knowledge in all areas of everyday life and work. e-Literacy in the context of the project was defined as basic computer literacy, internet and e-mail literacy and mobile literacy. A citizen who was e-literate would possess the ability to take online courses and qualify for higher positions within the work environment or improve productivity at work.

$\boldsymbol{e}$-Astuteness: To develop an e-competent individual by giving the individual appropriate ICT-related knowledge and skills and training to develop a competent attitude and knowledge to use and to adapt to the rapidly changing new forms of ICT devices and associated software" (National Department of Communications, 2013 ). e-Literacy was the basic skill required to become e-astute.

e-Social astuteness: denoted a smart way of applying acquired e-skills and e-astuteness for everyday socio-economic development and better life opportunities for local benefit in a socio-economic dynamic increasingly impacted by new forms of ICT (National Department of Communications, 2013).

The South African Government recognized that it was not possible to deal with the inequality and poverty of the past or to build an inclusive economy and a capable and developmental state without appropriation of modern information and communication technologies (ICTs) across the full socio-economic spectrum. It was widely accepted that the development and enhancement of e-skills (digital skills) amongst the citizens of the country would enable the citizens to participate more equitably in a societal environment that is increasingly dominated by ICT. This was particularly relevant to previously disadvantaged groups including unemployed youth, elderly, women and people with disabilities. However, a more coordinated approach was required in South Africa and the national entity called the iNeSI (Ikamva National e-Skills Institute), which is referred to in the NeSPA document, was thus established. At the time of the case, the relevant Act, Bill and other legislative frameworks relating to the iNeSI institute were still work in progress.

Since 2010, numerous changes had taken place in the government structures of the republic and the eSI was moved to a different government department called Department of Telecommunication and Postal Services (DTPS). It had also been put under the auspices of NEMISA temporarily, until the process for the establishment of iNeSI was completed.

The eSI collaborated with various universities across South Africa and sought to reach out to as many communities in all the provinces as possible. VUT, being located in the Southern Gauteng Province, was 
one of the universities the eSI partnered with in 2010 as part of the project. The other universities were University of Western Cape (UWC - Western Cape), Durban University of Technology (DUT - Kwazulu Natal), Walter Sisulu University (WSU - Eastern Cape) and University of Pretoria (UP - Gauteng). Each of the universities was assigned a thematic area as reflected in Exhibit 3.

VUT had the thematic area of “The Knowledge Economy \& e-Social Astuteness (e-literacy)”. In essence, this meant that the VUT CoLab was responsible for the e-literacy training of 10 million ordinary citizens by 2030 to enable them to participate in the knowledge-economy of SA. The term "e-literacy" was initially very loosely defined and was therefore left to the VUT CoLab to define.

Some of the day to day activities that required e-literacy are the following: e-mailing, typing letters, undertaking research, searching for online journals through library websites, registering for conferences or just looking for a Sunday lunch recipe. However, the reality was that millions of people in South Africa did not have basic e-skills. Digital skills had also become an essential basic life skill. The VUT CoLab, in partnership with NEMISA/INeSI, were the leading government agencies tasked with ensuring that South Africans possessed the requisite e-skills.

The e-skills (e-literacy) program that was developed for this purpose was targeted at everyone who was not technology savvy. In South Africa "everyone” referred to people in urban, peri-urban, rural and even deep rural areas. Within the South African e-skills framework, these e-skills users were classified according to different categories including non e-literate communities, e-users, e-practitioners, e-leaders, entrepreneurs, government and the general public. Exhibit 4 lists these categories, as defined in the South African context.

Another factor that contributed to the lack of e-skills in the republic was the shortage of the necessary broadband infrastructure in the country and therefore the lack of opportunities to learn and have access to technology as basic as internet and e-mail.

\section{e-Skills at the VUT}

\section{Overview of e-Skills Programme at VUT}

The Vaal University of Technology (VUT) was one of the 26 higher education institutions in South Africa, situated in the Southern part of the Gauteng Province with 4 satellite campuses. Its staff were all employed between Peromnes (job) levels 1 and 18, of which a rating scale of 1 was the highest and 18 the lowest. Most admin and academic staff were appointed on levels 5-12, while service workers were appointed mostly on levels 13-18. VUT was in the process of rolling out a new performance management system and each employee had the responsibility to prepare a personal development plan (PDP) in conjunction with his or her performance level agreement. If any employee wanted to go on training, it had to be aligned with their PDP. For academic and administrative employees, there were numerous opportunities for skills development in terms of their job function and role within the university. For example, IT Academics could go on an Oracle Course for trainers to enable them to teach Oracle better to $3^{\text {rd }}$ year students. Alternatively, a finance worker could attend a course on new tax regulations. For internal training, a Centre for Academic Development (CAD) was established for academics. 
The skills development of service workers and low level employees was, however, not catered for by the CAD. Thus, very few opportunities for skills development existed for these workers. One such skill that was not adequately addressed was e-literacy of these workers. This omission contributed further to an already disengaged group of employees. Although e-literacy was not a direct requirement for the service workers within their job environment, it was seen as an opportunity to uplift their skills for selfimprovement, thereby allowing these employees to partake in the e-communication strategy of the university. Some of the e-communication systems used in the university included things such as the payslip system and the application of leave system from the HR Department of the University.

In the University, the e-skills programme was located within the VUT CoLab. The focus of the CoLab was to "mobilize the broader population including the unemployed, low income levels and broad community structures (prioritising woman and disabled) into the socio-economic mainstream to make them competitive, employable, entrepreneurial and self-sustaining by supporting business and community development through general programs and support functions”.

The VUT CoLab operated by establishing partnerships with existing centres all over Southern Gauteng and the Northern Cape. The minimum requirements for a centre to become a partner were a working computer laboratory (with an internet connection where possible) that was accessible to the community and a designated centre manager / facilitator who was in good standing with the community leaders and the community at large. This was part of the development process of local talent within the different communities.

\section{e-Skills Training for Service Staff at VUT}

Although the focus of the VUT CoLab was on the unemployed youth and the communities at large, VUT felt that they also had to contribute to the development of their own staff. The service workers of VUT, who were involved in this training, formed part of the non e-literate community and were therefore seen as an ideal target group for e-literacy training.

Antoinette, was approached by HR to see whether the e-literacy course for service workers was an option to improve their engagement and social upliftment. Antoinette deemed the e-literacy course as the foundation for development and engagement of these service level employees to enhance their eastuteness. The e-skills unit was focused on basic e-literacy for all staff and students, while the CAD was more focused on the development of skills relating to the e-learning delivery platform.

The e-literacy course consisted of basic computer skills, internet and email and skill in mobile technology. The e-literacy course was introduced to the first group of 50 service workers in 2015 over a period of 6 months in a facilitated environment. There was no pre-test given to the participants, only a questionnaire asking questions regarding their previous experience in the use of technology and their access to technology. Participants also went through a short interview to establish their basic English communication skills. During the first class, an introduction and proper orientation was given on how to switch on a computer, use a mouse and login to the online e-literacy program. During the course, students would work through the online material, with a facilitator explaining some of the concepts and applications when and where required. At the end of each topic, the facilitator would revise the content and give a practical exercise to assist the students to practice their skills in real life applications.

The training of these service workers was undertaken as part of the CoLab's pilot to test the content, the methodology of teaching and the success of the assessment system. Of the 50 participants in the initial 
group, 10 cancelled or dropped out of the course due to various reasons, and 1 participant died in a tragic accident. Of the 39 remaining participants $6(15 \%)$ passed all the modules after writing the first exam, and 8 (20.5\%) passed at least three of the six modules at the first attempt of the exam.

The main concern regarding the exam results revolved around the fact that too few participants actually passed all 6 modules with the required pass mark of 60\%. During the analysis of the results, it was clear that most of the participants struggled with the more advanced topics like mail merge and advanced formulas used in Excel.

The students who did not qualify for a certificate of competence received a certificate of attendance.

\section{Specifics of the e-Literacy Training Program}

The eSkills4All program was selected as the program of choice for e-literacy training. This program was a locally developed product that was geared towards the South African market in the following ways:

- Localized for the South African environment. All the content was developed whilst taking into consideration the culture, context and South African environment. In this regard, only concepts known to South Africans were used. For example, no foreign towns or city names such as New York or London were used. In contrast, only cities and towns such as Johannesburg and Soweto, which are well known to the South African population, were used. Games were linked to soccer, a well-known and supported sport in South Africa.

- Basic requirements of reading and writing in English. This e-ESkills4All program was developed to address the limitations that are often encountered by $2^{\text {nd }}$ and $3^{\text {rd }}$ English language speakers.

- Assessments were linked to SAQA credits: This linkage meant that participants, if they so wished, could complete a full End-User computing course and get an accredited certificate from SAQA (South African Qualifications Authority). SAQA was a statutory body, regulated in terms of the National Qualifications Framework Act No. 67 of 2008 of South Africa.

- Available online / off-line (local): Although the use of a complete online solution for e-literacy would be ideal, due to the existing skill level of citizens, the only viable approach was a blended approach. Blended learning was a teaching methodology, which combined traditional classroom methods with online digital media. This teaching methodology required both the learner and the teacher or facilitator to be present in the classroom.

- Accredited by VUT as a non-formal Short Learning Programme. The e-literacy programme went through an evaluation process for it to be registered as a non-formal Short Learning Program at VUT. Following a proper evaluation by various and relevant stakeholders, the e-literacy programme was finally approved.

The course consisted of the following modules:

- Introduction to computers

- Internet and E-mail

- Word-processing

- Spreadsheets

- Presentation software 
Exhibit 6 indicates the different topics per modules and the related NQF levels of each topic. Exhibit 6 also indicates the SAQA unit standard number and credits linked to the unit standard, for those students who wished to complete a full qualification.

The pedagogy of "Teach, Show, Do" was used throughout the program and allowed the course participants to practice concepts in the actual learning program. The assessment was a fully automated, online assessment system and was conducted at the end of the training course. This assessment consisted of 6 modular assessments. Students had 45 to 60 minutes to complete each assessment depending on the module being assessed. For example, the assessment for the Introduction to Computer module was shorter than that of the Microsoft Word module. The assessment included both theoretical and application questions.

\section{The Decision}

From the engagements with HR, the course facilitator, and the participants, it was realized that the level of the course might be too high for the participants in the program. This was mainly due to the fact that some of the topics in the courseware were pitched at NQF Level 4 (see Exhibit 6). In South Africa NQF Level 4 was equal to grade 12 (also called matric), which is the exit level at high school. Students were required to pass grade 12 with the required marks in order to enroll for tertiary level studies in the country. As blue collar workers, a grade 12 qualification was not a job requirement for the service workers or any of the participants in the e-literacy course. It was therefore not surprising that the participants struggled with the course modules, which were pitched at NQD Level 4 or grade 12.

The decision Antoinette faced was how to improve the first attempt pass rate. Retaining the relevance and focus of the course was an important factor to consider when reaching this decision. Antoinette felt that taking away some of the higher level modules could have a negative impact on the expected outcomes of the e-literacy course. It was envisioned that the skills acquired from some of these higher level modules would have improved the chances of the participants in securing better jobs. On the other hand, the exclusion of these higher level modules from the course could exert a negative influence on the motivation of the participants to complete the entire course because they repeatedly failed these more difficult modules.

In the end, Antoinette had to consider the several available options since she remained concerned about the real impact of the course.

Option one involved changing the levels of learning achievements of the course by removing the more difficult modules pitched at NQF Levels 3 and 4, without necessarily watering down the focus of the course. Although this seemed to be the easiest option, it meant that certain skills, which the participants would need to secure better paying jobs, would therefore not be acquired through this course. Such a move would also have had an impact on the students who wished to complete the full qualification that encompasses specific NQF Levels and SAQA Unit standards.

The second option was to change the facilitation mode from totally facilitated to a more blended approach. The mode of contact during the training of the first group was mostly facilitator-led, whereby the facilitator would discuss a certain topic for the day and thereafter allow the students to go through the content using the e-skills4all software. Once the students had completed the online part of the course in class, the facilitator would do a revision of the material covered earlier in class and thereafter instruct the students to complete the relevant exercises so as to instill knowledge through application questions. For 
example, upon completion of the Word module, the students were asked to type a CV, integrating all the concepts learnt in class.

In the blended mode, the facilitator went through the program step-by-step with the students instead of leaving them to work on their own. Changing the class facilitation format to a more blended approach meant the facilitator would allow the students to work through the content on their own while providing the requisite assistance as and when required by the students. Where necessary, the more difficult modules would be discussed in class in greater detail and relevant examples would be used to reinforce the learning process. Thereafter, the class would be assigned practical exercises to complete.

The third and last option involved the inclusion of additional exercises containing more application type questions to instill the e-astuteness principles, without removing the more difficult modules (i.e. NQF Levels 3 and 4 modules). This option would require that the course be extended for an additional week or two, depending on the capabilities of the students. The extension, it was argued, would have had a negative influence on the work environment of the service workers since they would have to be away from work for a longer period of time.

\section{References}

National Department of Communications. The National e-Skills Plan of Action. National Department of Communications. 2013 


\section{Authors}

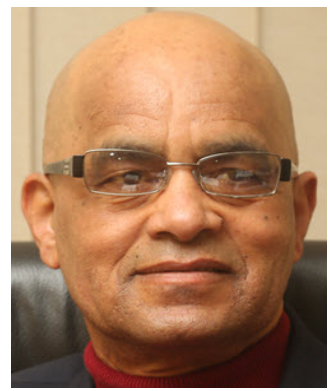

Dr. Robert Martin presently holds the position of Deputy Vice Chancellor Operations at the University of Venda, Limpopo Province, South Africa. He has previously worked as Executive Director Strategic Alliances, at the Vaal University of Technology. Robert holds a PhD in Entrepreneurship and his research interest are in the areas of entrepreneurship, small business development, strategic planning, management and e-learning.

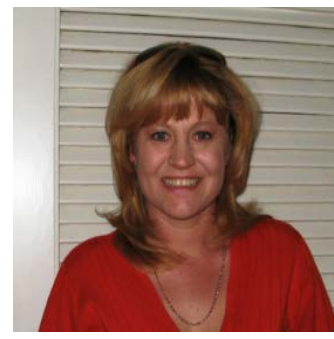

Mrs Antoinette Lombard (BTech and MTech) is currently the Director: eSkills at the Vaal University of Technology CoLab. This CoLab is one of the partners involved in the rolling-out of a program aimed at e-skilling the South African nation in partnership with the South African Government. She is a committee member of the Northern Cape Broadband Committee, Northern Cape Skills Forum and ICT Skills Forum of the Gauteng Economic Forum Cluster. 


\title{
Exhibit 1: Provinces of South Africa
}

\section{THE NINE PROVINCES OF SOUTH AFRICA}

\author{
Limpopo
}

North Gauteng Mpumalanga West

\section{Free State \\ KwaZulu- \\ Natal}

Northern Cape

\section{Eastern Cape}

\section{Western Cape}




\section{Exhibit 2: Population by Province}

\begin{tabular}{|l|c|c|c|}
\hline Province & $\begin{array}{l}\text { \% of National } \\
\text { land area }\end{array}$ & $\begin{array}{l}\text { Population } \\
\text { Percentage } \\
\text { (\%) }\end{array}$ & $\begin{array}{l}\text { Population in numbers } \\
\text { (Million) }\end{array}$ \\
\hline Eastern Cape & 13.8 & 12.7 & 6.56 \\
\hline Free State & 10.6 & 5.3 & 2.74 \\
\hline Gauteng & 1.4 & 23.7 & 12.27 \\
\hline KwaZulu-Natal & 7.7 & 19.8 & 10.27 \\
\hline Limpopo & 10.3 & 10.4 & 5.40 \\
\hline Mpumalanga & 6.3 & 708 & 4.04 \\
\hline Northern Cape & 30.5 & 2.2 & 1.15 \\
\hline North West & 8.7 & 6.8 & 3.50 \\
\hline Western Cape & 10.6 & 11.2 & 5.82 \\
\hline
\end{tabular}




\section{Exhibit 3: e-Skills Thematic Areas Covered by Universities}

\begin{tabular}{|l|l|l|}
\hline National e-Skills Thematic Area & Current Hosting University & Province \\
\hline E-government /governance & Durban University of Technology (DUT0 & Kwazulu-Natal \\
\hline Creative New Media & Tshwane University of Technology (TUT) & Gauteng \\
\hline e-Inclusion and social innovation & University of the Western Cape & Western Cape \\
\hline $\begin{array}{l}\text { Knowledge-based economy and e- } \\
\text { literacy }\end{array}$ & Vaal University of Technology (VUT) & $\begin{array}{l}\text { Southern Gauteng } \\
\text { \& Northern Cape }\end{array}$ \\
\hline $\begin{array}{l}\text { ICT for rural development including } \\
\text { production and distribution }\end{array}$ & Walter Sisulu University (WSU) & Eastern Cape \\
\hline Connected Health & University of Limpopo & Limpopo \\
\hline Tourism and agriculture & North West University & North West \\
\hline
\end{tabular}




\section{Exhibit 4: User and Stakeholder Categories}

\begin{tabular}{|l|l|}
\hline Category of users & Description in South African Context \\
\hline $\begin{array}{l}\text { Non e-literate } \\
\text { communities (people } \\
\text { who are not savvy }\end{array}$ & $\begin{array}{l}\text { These people may know very little or nothing about technology. They need } \\
\text { e-skills to help themselves secure better employment opportunities and to } \\
\text { improve their everyday lives This was particularly important for sections of } \\
\text { the population that had been marginalised and needed to be included in the } \\
\text { economy. Non e-literate communities included the elderly, the } \\
\text { unemployed, unskilled youth, and women. }\end{array}$ \\
\hline e-Users & $\begin{array}{l}\text { These were people that required e-skills to do their everyday jobs. (This } \\
\text { does not necessarily mean people who are responsible for ICT, such as IT } \\
\text { technicians who look after computer matters at the workplace.) }\end{array}$ \\
\hline e-Practitioners & $\begin{array}{l}\text { These were people whose job it is to work with ICT, (e.g. developing } \\
\text { solutions). There were hundreds of jobs that fell into this category. These } \\
\text { included programmers, mobile app developers, website developers and } \\
\text { database administrators. }\end{array}$ \\
\hline e-Leaders & $\begin{array}{l}\text { These were people who use technology to develop their organisations. e- } \\
\text { Leaders were using ICT as a tool and this group included CEOs and CIOs. } \\
\text { (The CIO, or Chief Information Officer in general looked at the technology } \\
\text { needs for the business.) }\end{array}$ \\
\hline Entrepreneurs & $\begin{array}{l}\text { Entrepreneurs were an important part of our economy and key to making it } \\
\text { grow. It was essential for them to have the e-skills needed to run their } \\
\text { businesses successfully, whether these were very small businesses or larger } \\
\text { businesses. They need to know how to use budgeting programmes, stock } \\
\text { control programmes and how to market online including using the internet } \\
\text { and social media to promote their services and products. }\end{array}$ \\
\hline Government & $\begin{array}{l}\text { The South African government was on a drive to have more efficient } \\
\text { government services. This could have been done using ICT. For example, a } \\
\text { lot of government services could be provided through the internet. It was } \\
\text { essential that people who work in government had the e-skills to provide } \\
\text { effective service delivery. }\end{array}$ \\
\hline
\end{tabular}




\section{Exhibit 5: Maps of CoLab centres}

Southern Gauteng centres

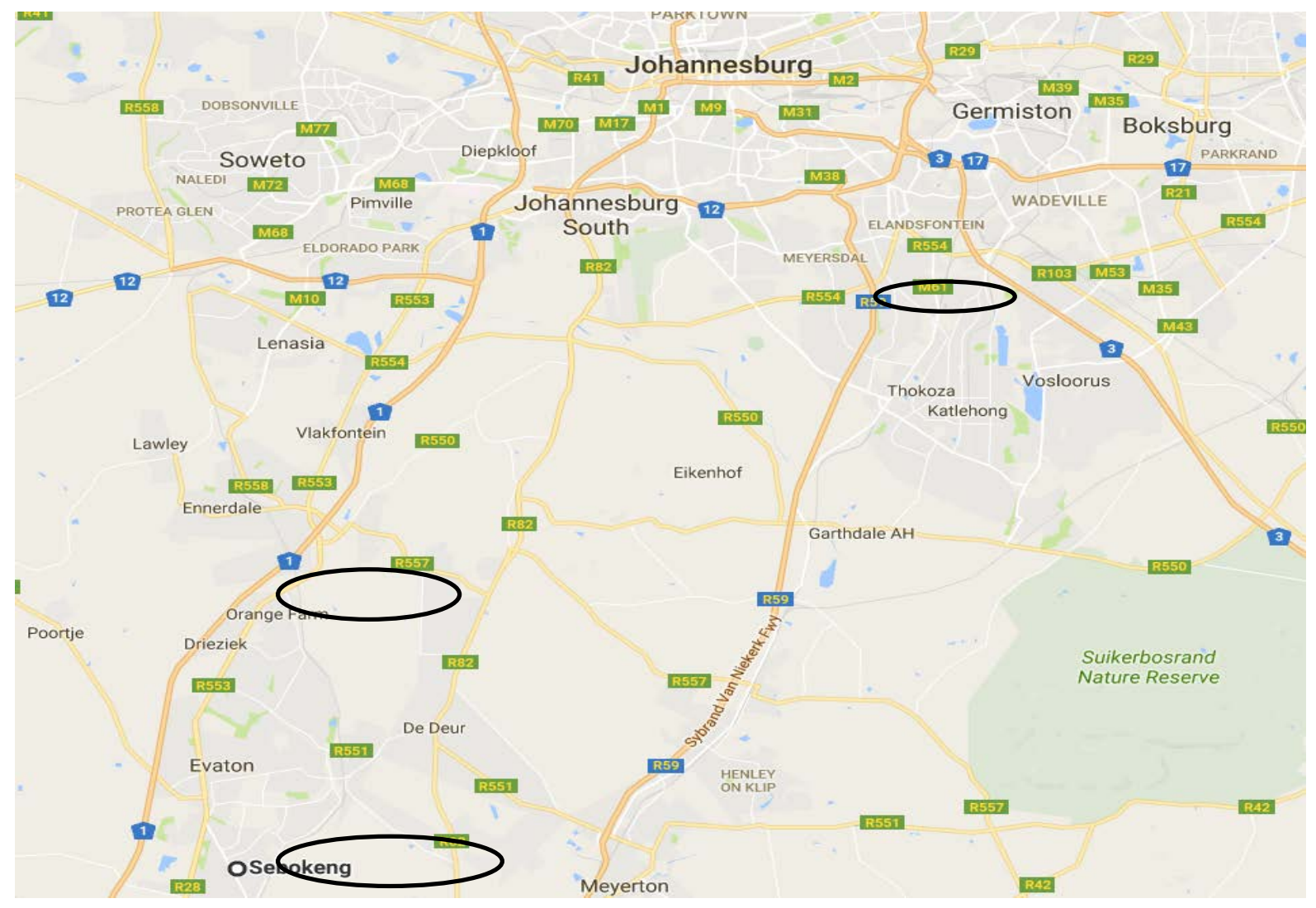




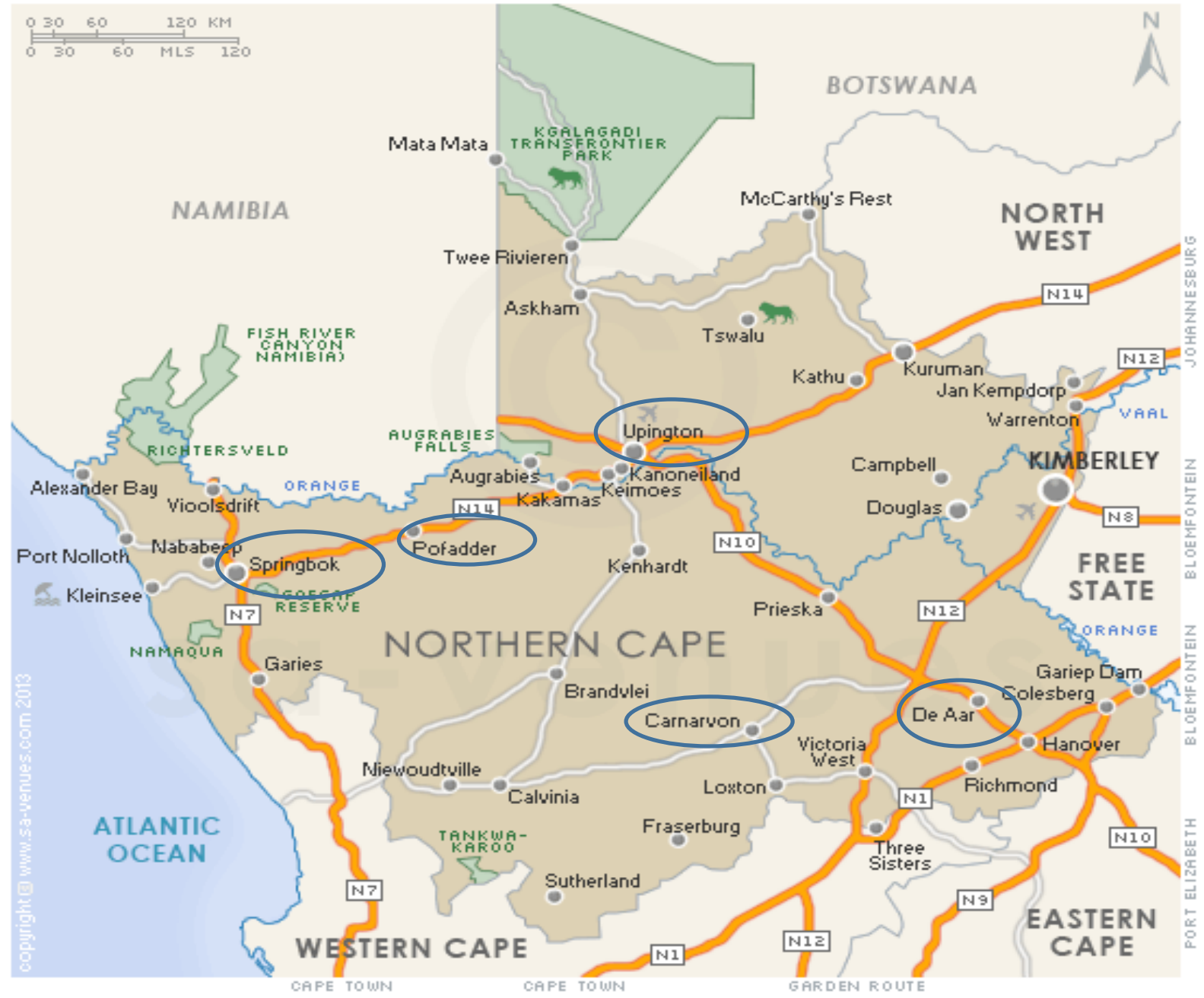

\section{Northern Cape Centres}




\section{Exhibit 6: Modules and Topic Areas for Current Course}

\begin{tabular}{|c|c|c|c|c|}
\hline \multicolumn{2}{|c|}{$\begin{array}{l}\text { Module } \\
\text { Unit Standard \& Topics Covered }\end{array}$} & \multirow{2}{*}{\begin{tabular}{|l} 
SAQA \\
NQF Unit \\
$\begin{array}{l}\text { Standard } \\
\text { Number }\end{array}$ \\
116932 \\
\end{tabular}} & \multirow{2}{*}{$\begin{array}{c}\text { NQF } \\
\text { Level } \\
\\
1\end{array}$} & \multirow{2}{*}{$\begin{array}{c}\text { Credits } \\
3\end{array}$} \\
\hline \multirow{4}{*}{$\begin{array}{l}\text { Introduction } \\
\text { Computers }\end{array}$} & Operating a Computer & & & \\
\hline & Managing Files and Folders & 117867 & 1 & 3 \\
\hline & Using Computer Functions & 258883 & 1 & 4 \\
\hline & Concepts and Uses of ICT & 117925 & 2 & 3 \\
\hline \multirow[t]{3}{*}{ Internet \& E-mail } & Managing Email & 116935 & 2 & 2 \\
\hline & Using an Email Application & 116945 & 2 & 2 \\
\hline & $\begin{array}{l}\text { Introduction to the internet and } \\
\text { web-browsers }\end{array}$ & 116931 & 2 & 4 \\
\hline \multirow[t]{4}{*}{ Microsoft Word } & Document Creation & 116938 & 1 & 4 \\
\hline & Formatting Documents & 117924 & 2 & 5 \\
\hline & Create Merged Documents & 116942 & 3 & 3 \\
\hline & Using Tables and Columns & 119078 & 3 & 5 \\
\hline \multirow[t]{3}{*}{ Microsoft Excel } & Working with Spreadsheets & 116937 & 2 & 4 \\
\hline & $\begin{array}{l}\text { Editing and Formatting } \\
\text { Spreadsheets }\end{array}$ & 116940 & 3 & 6 \\
\hline & $\begin{array}{l}\text { Enhancing Spreadsheets with } \\
\text { Objects }\end{array}$ & 116943 & 4 & 3 \\
\hline \multirow{3}{*}{$\begin{array}{l}\text { Microsoft } \\
\text { PowerPoint }\end{array}$} & Creating a Presentations & 116933 & 1 & 3 \\
\hline & Formatting a Presentation & 117923 & 2 & 5 \\
\hline & Enhancing a Presentation & 116930 & 3 & 5 \\
\hline Total & & 17 & & 64 \\
\hline
\end{tabular}

